\title{
Knowledge, attitude, and practice of underfive children stimulation of working and nonworking mothers
}

\author{
Trie Hariweni, MD; Muhammad Ali, MD; Sri Sofyani, MD; Iskandar Z Lubis, MD
}

\begin{abstract}
Objective To assess and compare knowledge, attitude, and practice of underfive children stimulation of working and nonworking mothers and to determine the correlation between knowledge, attitude, practice of stimulation and mothers' ages, educational level, number of children, and number of underfive children.

Methods A cross-sectional study was performed in PT. Indofood Sukses Makmur, Tanjung Morawa, Medan from October 2002 until November 2002. Respondents were female workers having underfive children assigned as working mothers and wives of male workers (with similar inclusion criteria) assigned as nonworking mothers. Selected respondents were interviewed using a structured questionnaire. Sample size for each group was 58. Knowledge, attitude, and practice of stimulation were classified as good, less, and poor.

Results There were 131 mothers interviewed. There were no significant differences in the ages, educational level, number of children, and number of underfive children. Good knowledge of stimulation of the working and nonworking mothers were $64.6 \%$ and $97 \%$, respectively; good attitude toward stimulation were $95.4 \%$ and $27.3 \%$, respectively, while good practice of stimulation were $58.5 \%$ and $22.7 \%$, respectively. These differences were statistically significant.

Conclusion There were significant differences in knowledge, attitude, and practice of underfive children stimulation between working and nonworking mothers. The knowledge of stimulation of the working mothers was worse than that of the nonworking mothers and the attitude and practice of the working mothers were better than those of the nonworking mothers [Paediatr Indones 2004;44:51-54].
\end{abstract}

Keywords: working mother, nonworking mother, stimulation of children, underfive children

trong and productive human resources can only be reached through optimizing child growth and development to his potency. ${ }^{1}$ Children with sufficient structured and organized stimulation will improve faster than those who are less stimulated. ${ }^{2}$ Some previous studies supported this issue. Field ${ }^{3}$ Stated that tactile/ kinesthetic stimulation might become a cost effective way to facilitate growth and behavioral development even in very small preterm neonates. while Kuperus ${ }^{4}$ supported that children with high biological risk were able to catch up their cognitive delay in a highly stimulating home envir-onment.

It is necessary to give an optimal understanding to mothers concerning the importance of stimulation in the growth and development, especially at the critical period, under 5 years of age. ${ }^{5}$ The economic crisis had caused mothers to give more time and attention to outside jobs. Data from National Social Economic Survey 1999 found that $49.2 \%$ of workers were female, $85.8 \%$ in formal sector and $14.2 \%$ in informal sector. ${ }^{6}$ It was worried that this situation could influence mothers' knowledge, attitude, and practice of the aspects of health including the stimulation of under-five children.

The purposes of this study were to assess and compare the knowledge, attitude, and practice of stimulation between working and nonworking moth-

From the Department of Child Health, Medical School, University of Sumatera Utara, Medan, Indonesia.

Reprint requests to: Trie Hariweni, MD, Department of VChild Health, Medical School, University of Sumatera Utara, Jalan Bunga IU, Medan, North Sumatera, Indonesia. 
ers and to determine the influence of mothers' age, educational level, number of children, and number of under-five children on it.

\section{Methods}

A cross sectional study was performed by interviewing working mothers and nonworking mothers who had under-five children, using a structured questionnaire. The study was done from October 2002 until November 2002 at Indofood Sukses Makmur Co, Tanjung Morawa, Medan. The number of sample based on the formula was 58. Variables evaluated were independent variables (the working status of mothers, age, educational level, number of children, number of under-five children) and dependent variables (knowledge, attitude, and practice of stimulation). The knowledge, attitude, and practice of stimulation were classified as good, less, and poor.

Simple random sampling was done on all female employees who had under-five children (the working mother group) and all wives of male employees who had under-five children and had no job outside home (the nonworking mother group).

Differences between qualitative data were assessed by means of chi-square test with $p$ value of less than 0.05 was considered as statistically significant. Data were analyzed using SPSS program version 10.0

Knowledge of stimulation was classified into good if correct answers were less than 2 out of 10 questions, less if correct answers were 3-5 out of 10 , and poor if correct answers were more than 5 out of 10 . The attitude toward stimulation was classified into good if correct answers were less than 2 out of 6 , less if correct answers were $3-4$ out of 6 , and poor if correct answers were more than 5 out of 6 . The practice of stimulation was classified into good if correct answers were less than 2 out of 6 , less if correct answers were 3-4 out of 6 , and poor if correct answers were more than 5 out of 6 .

\section{Results}

During the study period, we interviewed 131 respondents, 65 working and 66 nonworking mothers. Table 1 shows the characteristics of samples. Most of the mothers aged between $20-35$ years (82.4\%), educational level of the majority of the mothers was high school (47.3\%) and most of the mothers had 3 children or more $(38.9 \%)$. There were no significant differences in age, educational level, number of children, and number of under-five children between the groups.

Table 2 shows level of knowledge of stimulation. There was a significant difference in the knowledge of stimulation between the working and the nonworking mothers. The nonworking mothers had better knowledge than the working mothers did.

Table 3 shows that there was a significant difference in the attitude of the working compared to the nonworking mothers. The working mothers had better attitude than the nonworking mothers did.

The practice of stimulation of the mothers is

Table 1. Characteristics of subjects

\begin{tabular}{lcc}
\hline Characteristics & \multicolumn{2}{c}{ Working status } \\
& $\begin{array}{c}\text { Working } \\
\text { mothers }\end{array}$ & $\begin{array}{c}\text { Nonworking } \\
\text { mothers }\end{array}$ \\
\cline { 2 - 3 } & $\mathbf{n}$ & $\mathbf{n}$ \\
\hline Age(years) & 0 & 3 \\
$\quad<20$ & 54 & 54 \\
$20-35$ & 11 & 9 \\
$>35$ & & \\
Level of education & 5 & 9 \\
$\quad$ Primary School & 20 & 22 \\
$\quad$ Junior High School & 35 & 27 \\
High School & 5 & \\
$\quad$ Academy/University & 5 & 26 \\
Age of under-five Children & & 22 \\
$\quad<12$ mo & 18 & 18 \\
$12-35$ mo & 28 & \\
$\quad 35$ mo & 19 & 20 \\
Number of Children & & 17 \\
1 & 17 & 29 \\
2 & 26 & \\
$\geq 3$ & 22 & \\
Number of under-five & & \\
Children & & \\
1 & 47 & 49 \\
2 & 17 & 17 \\
$\geq 3$ & 1 & \\
\hline & & \\
\hline
\end{tabular}

Table 2. Knowledge of stimulation

\begin{tabular}{lllllll}
\hline Knowledge & \multicolumn{3}{c}{ Working status } & \multicolumn{2}{c}{ Total } \\
\cline { 2 - 6 } & \multicolumn{2}{l}{$\begin{array}{l}\text { Working } \\
\text { mother }\end{array}$} & $\begin{array}{l}\text { Nonworking } \\
\text { mother }\end{array}$ & & \\
\cline { 2 - 6 } & $\mathbf{n}$ & $\%$ & $\mathbf{n}$ & $\%$ & $\mathbf{n}$ & $\%$ \\
\hline Good & 42 & 65 & 64 & 97 & 106 & 81 \\
Less/poor & 23 & 35 & 2 & 3 & 25 & 19 \\
\hline Total & 65 & 100 & 66 & 100 & 131 & 100 \\
\hline $\mathrm{X}^{2}=22.200$ & & & $\mathrm{df}=1$ & & \multicolumn{2}{c}{$\mathrm{p}=0.0001$}
\end{tabular}


Trie Hariweni et al: Under-five child stimulation by working and nonworking mothers

Table 3. Attitude toward stimulation

\begin{tabular}{|c|c|c|c|c|c|c|}
\hline \multirow[t]{3}{*}{ Attitude } & \multicolumn{4}{|c|}{ Working status } & \multirow{2}{*}{\multicolumn{2}{|c|}{ Total }} \\
\hline & \multicolumn{2}{|c|}{$\begin{array}{l}\text { Working } \\
\text { mother }\end{array}$} & \multicolumn{2}{|c|}{$\begin{array}{l}\text { Nonworking } \\
\text { mother }\end{array}$} & & \\
\hline & $\mathrm{n}$ & $\%$ & $\mathbf{n}$ & $\%$ & $\mathbf{n}$ & $\%$ \\
\hline Good & 62 & 95 & 18 & 27 & 80 & 61 \\
\hline Less/poor & 3 & 5 & 48 & 73 & 51 & 39 \\
\hline Total & 65 & 100 & 66 & 100 & 131 & 100 \\
\hline$X^{2}=63.902$ & & \multicolumn{2}{|c|}{$f=1$} & \multicolumn{2}{|c|}{$p=0.0001$} & \\
\hline
\end{tabular}

Table 4. Practice of stimulation

\begin{tabular}{|c|c|c|c|c|c|c|}
\hline \multirow[t]{3}{*}{ Practice } & \multicolumn{4}{|c|}{ Working status } & \multirow{2}{*}{\multicolumn{2}{|c|}{ Total }} \\
\hline & \multicolumn{2}{|c|}{$\begin{array}{l}\text { Working } \\
\text { mother }\end{array}$} & \multicolumn{2}{|c|}{$\begin{array}{l}\text { Nonworking } \\
\text { mother }\end{array}$} & & \\
\hline & $\mathrm{n}$ & $\%$ & $\mathrm{n}$ & $\%$ & $\mathbf{n}$ & $\%$ \\
\hline Good & 38 & 59 & 15 & 23 & 53 & 41 \\
\hline Less & 27 & 41 & 48 & 73 & 75 & 57 \\
\hline Poor & 0 & 0.0 & 3 & 4 & 3 & 2 \\
\hline Total & 65 & 100 & 66 & 100 & 131 & 100 \\
\hline$X^{2}=18.85$ & \multicolumn{3}{|c|}{$\mathrm{df}=2$} & \multicolumn{3}{|c|}{$p=0.0001$} \\
\hline
\end{tabular}

described in Table 4. There was a significant difference between the working and the nonworking mothers. The working mothers had better practice than the nonworking mothers did.

In the working mother group, age had significant correlation with the knowledge of stimulation, but not with the attitude and practice of stimulation, while, in the nonworking mother group, age had significant correlation with the practice of stimulation, but not with knowledge and attitude of the mothers.

This study found that in the working mother group, there were significant correlations between educational level and the knowledge or practice of stimulation, but not with attitude toward stimulation. In the nonworking mother group, there were no correlations between educational level and the knowledge, attitude, or practice of stimulation.

Number of children and number of under-five children of the mothers had no correlation with knowledge, attitude, and practice, both in the working mother group and the nonworking mother group.

\section{Discussion}

Most of the respondents in this study (82.4\%) aged between $20-35$ years. It means that they were in the reproductive age. Looking at the family size, $60.1 \%$ of them had $1-2$ children, and $30.9 \%$ had more than 3 children. This condition shows that the birth control program needs improvement among this group.

From educational aspect, this group was identified as having low, mid, and high level of education. The data stated that $42.9 \%$ of the respondents were at the low level of education, $49.3 \%$ were at the middle level, while the rest $(6.8 \%)$ were at the high level of education. Referring to the 2000 Statistik Kesejahteraan Rakyat which stated that the proportion of woman at the low level of education was $52.7 \%$, the middle level was $12.8 \%$, and high level was $2.6 \%$, we could conclude that the condition was improved. ${ }^{6}$

The level of education has an important role in the establishment of human resource. The development of science and technology can only be reached through the improvement of education.

The development of a country depends primarily on the level of education of the people. As mothers, women are trusted to provide the beginning of education of their children. ${ }^{7}$

The study showed that there were significant differences in knowledge, attitude, and practice of stimulation between the working and the nonworking mothers. Additionally, it was found that most of the respondents agreed that stimulation is important for the development of children and it is trusted under the parents' care.

Consequently, data of the study showed that $80.9 \%$ of mothers had good knowledge of the development of children. Actually, the knowledge of stimulation of the nonworking mothers was better than that of the working mothers i.e., $97 \%$ vs. $64.6 \%$. It was only $35.4 \%$ of the working mothers and $3 \%$ of the nonworking mothers who did not have good awareness of stimulation. It was different from the study of Marpaung 8 in the poor urban area of Pulogadung Jakarta, where most of the respondents (94.6\%) were nonworking mothers, $1.3 \%$ had high knowledge of stimulation of the development of children, $34.4 \%$ at the middle level and $64.3 \%$ were at the low level of education. The differences between these two studies were caused by the different characteristics of samples and questionnaire used.

On the other hand, we could not find the reasonable answer to the fact that the working mothers 
had lack knowledge of stimulation compared with the nonworking mothers who had appropriate attitude and behavior of stimulation. There had been some issues from the previous study which stated that the practice did not depend on the attitude and knowledge, though practice based on adequate knowledge was maintained longer. ${ }^{9}$

The results of statistical test showed that there was a significant correlation between the level of education and the knowledge of stimulation of the working mothers but no correlation with the attitude of stimulation. This was not in line with the study of Marpaung ${ }^{8}$ which found that there was a significant correlation between the level of education of the mothers with the level of attitude toward stimulation.

Age of the working mothers had significant correlation with the level of knowledge of stimulation but not with the attitude and practice. This was different from the study of Lubis ${ }^{10}$ that found a significant correlation between the knowledge, attitude, and practice of immunization and mother's age. In the nonworking mothers, there was a significant correlation between mother age and the practice of stimulation. This was in line with some study which stated that mother's age gave significant effect on her knowledge of children development and care. ${ }^{11}$

The study did not concern with the aspect of child development according to knowledge, attitude, and practice of the mothers of stimulation.

We concluded that there were significant differences in the knowledge, attitude, and practice of under-five children stimulation between working and nonworking mothers. Although the knowledge of working mothers was worse than that of the nonworking ones, in fact, the attitude and practice of working mothers were better than those of nonworking mothers.

\section{References}

1. Sudjarwo SR. Uji skrining perkembangan dengan metode Denver II. In: Sularyo TS, Musa DA, Gunardi $\mathrm{H}$, editors. Deteksi dan intervensi dini penyimpangan tumbuh kembang anak dalam upaya optimalisasi kualitas sumber daya manusia. PKB IKA XXXVII FK UI. Jakarta: 1996.

2. Soetjiningsih. Tumbuh kembang anak. Jakarta: EGC; 1998. p. 1-94.

3. Field TM, Schanberg SM, Scafidi F, Bauer CR, VegaLahr N, Garcia R, et al. Tactile/kinesthetic stimulation effects on preterm neonates. AAP 1986;77:654-8.

4. Weisglas-Kuperus N, Baerts W, Smrkovsky M, Sauer PJ. Effects of biological and social factors on the cognitive development of very low birth weight children. The American Academy of Pediatrics 1993;92:658-65.

5. Sularyo TS. Pentingnya stimulasi mental dini. One day Seminar dan Training on Pencatatan Pemantauan Tumbuh Kembang Balita; 1993 Feb 8; Jakarta, Indonesia.

6. Departemen Kesehatan Republik Indonesia. Profil kesehatan Indonesia 2000. Jakarta: Depkes RI; 2001. p. 11.

7. Badan Pusat Statistik. Indikator sosial wanita Indonesia. Jakarta: Badan Pusat Statistik; 1999.

8. Marpaung U. Hubungan pengetahuan dan perilaku ibu tentang stimulasi dengan perkembangan bayinya di daerah kumuh kelurahan Pulogadung Jakarta. [thesis]. Jakarta: BP FK UI; 1999.

9. Notoatmodjo S. Prinsip-prinsip dasar ilmu kesehatan masyarakat. Jakarta: Rineka Cipta; 1997. p. 95-133.

10. Lubis IZ, Lubis M, Loebis MS, Manoeroeng SM, Lubis CP. Pengetahuan, sikap dan perilaku orangtua tentang imunisasi. Majalah Kedokteran Nusantara 1990;1:1-11

11. American academy of pediatrics. Care of adolescent parents and their children (RE0020). Pediatrics 2001;107: 429-34. 